ELORE (ISSN 1456-3010), vol. 18 - 1/2011.

Julkaisija: Suomen Kansantietouden Tutkijain Seura ry. [http://www.elore.fi/arkisto/1_11/ajank_hyry.pdf]

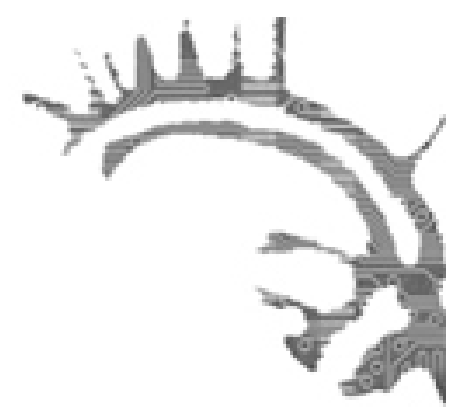

\title{
Ajankohtaista
}

\section{MEISTÄ JÄI TAAS JÄLKI}

Miten Vienan Pakolaiset ETSIVÄt PaikKaANSa, KERTOIVAT KOKEMASTAAN JA TULIVAT KUULLUIKSI 1900-LUVUN SUOMESSA

\section{$\underline{\text { Katja Hyry }}$}

\section{Lectio praecursoria Lapin yliopiston Taiteiden tiedekunnassa 9.4.2011}

On kesä 1989. On kaunis päivä, olen pyöräillyt Kemin kaupungin läpi vehreälle, kauniille omakotitaloalueelle. Siellä minua odottaa iäkäs ensimmäisen polven Karjalan pakolainen. Kun olen asetellut kelanauhurini pöydälle ja kiinnittänyt mikrofonin telineeseen, kysyn häneltä, mistä hän on kotoisin. Mies vastaa kysymykseeni näin:

Minä muistan sen kyllä hyvin kun kotoa lähettiin. Oli pilvinen taivas ja melko pimiä ja tykit jylisi, sieltä Kokkosalmesta kuulu hyvin meille se pauke. Oli yksi hevonen ja yhteen rekeen ei kovin paljon väkeä mahtunut kun siinä piti olla ruokaakin vielä matkassa. Ja sitte tultiin yksi kyläväli ja isä palasi mummon hakemaan vielä kotoa. Sitten oltiin kaikki yhdessä. Sitten me saimme lisähevosen. Siellä oli niitä pakolaisia varten joku hevonen, me saimme sitten. Minä hiihtelin Salmen, Salmenkylään asti, pitkä järvi semmonen oikein, kyllä se väsytti sillon jo. Sitte siitä pääsin rekeen ja kuskipukille istumaan sen kuskin viereen. Mulla oli semmonen turkki päällä ja minä olin kovasti väsyksissä ja minä putosin siitä kuskipukilta sinne tienpuoleen. Viimesestä hevosesta huomasivat että siellä joku mytty on siellä tienvieressä ja minut herättivät sieltä ja niihän minä pääsin taas istumaan ja sitte tultiin Kurvisenvaaraan. Siitä se alkoi se pakolaisen taival sitten.( SKSÄ 127-128.1991.) 
Kevättä 2011 on tiedotusvälineissä kutsuttu kansannousujen kevääksi. 1920-luvun vaihteessa elettiin myös kansannousujen aikaa. Monet vähemmistökansat pyrkivät irrottautumaan Neuvosto-Venäjästä ja kansalliset pyrkimykset nostivat päätään myös Itä-Karjalassa.

Tammi-helmikuussa 1922 lähti vienalaisista kylistä pakolaisia lähimpään mahdolliseen turvapaikkaan, vasta itsenäistyneeseen Suomeen. Näin tekee myös tänään suurin osa maailman 40 miljoonasta pakolaisesta. He ylittävät lähimmän rajan, riippumatta siitä, miten hyvin tuon rajan takana oleva maa on valmistautunut ottamaan pakolaisia vastaan.

\section{Vienasta SuOmeen}

Suomen itärajan ylitti 1920-luvun alussa kaikkiaan 33000 pakolaista. Heistä runsaat 11000 tuli Itä-Karjalasta. Sanotaan, että heidät ajoi liikkeelle "nälän, pelon ja politiikan" yhteisvaikutus. Takana oli epäonnistunut kansannousu, joka oli osa kansannousujen rintamaa. (Nygård 1980.)

Vasta itsenäistyneellä Suomella ei oikeastaan ollut valmiuksia näin suuren pakolaisjoukon vastaanottamiseen. Mutta vaihtoehtoja ei ollut. Ihmiset sijoittuivat entuudestaan tuttuihin taloihin rajapitäjissä. Pakolaisille perustettiin pakolaisleirejä ja myöhemmin myös pakolaiskouluja. Vanhuksille oli omia huoltoloita, joista viimeisin lakkautti toimintansa vasta 1970 Oulun Maikkulassa.

Pakolaiset etsivät töitä sieltä, mistä niitä löytyi. Monille ainoaksi mahdollisuudeksi jäi lakkorikkuriksi ryhtyminen Pohjois-Suomen suurilla tehdaspaikkakunnilla. Kemiin muodostui tiiviitä pakolaisyhteisöjä, joista merkittävimmät olivat Laitakarissa ja Veitsiluodossa. Saarilla oli mahdollista elää omien kanssa, omalla tavallaan, mutta myös sovussa muiden kanssa. Yhdistävä tekijänä ei ollut vain heimo, vaan myös asuinpaikka. Sahayhteisöistä muodostui pakolaisille turvapaikkoja, jotka houkuttelivat heimolaisia myös muualta Suomesta.

Sahayhteisöjen aika päättyi viimeistään sotien jälkeen. Myöhemmin niistä muodostui toisen polven pakolaisille samanlaisia muistelun kohteita kuin Karjalan kotikylät olivat ensimmäisille pakolaispolville. Myös sahasaarista tuli paikkoja, joissa oli hyvä elää ja joita ei enää ole.

Sotien jälkeen Kemin karjalaisten elämä muuttui myös muuten. Vuonna 1948 sadat Kemin karjalaiset jatkoivat pakomatkaansa toisen rajan yli Ruotsiin. Inkeriläisiä luovutettiin takaisin Neuvostoliittoon. Palautuksen pelossa myös monet karjalaiset lähtivät.

\section{HISTORIAKÄSITYKSEN JÄLJILLÄ}

Aloitin kenttätyöni kesällä 1989. Myös tuosta kesästä tuli käännekohta pakolaisten elämässä, vaikka sitä en vielä kenttätyötä aloittaessani tiennyt. Myös vuosi 1989 oli kansannousujen vuosi. Itäraja avautui, pakolaiset alkoivat tavata rajan taakse jääneitä sukulaisiaan. Näiden tapaamisten seuraaminen oli myös tutkimukseni kannalta käänteentekevää. 
Kiteytyneet, usein muistellut kertomukset kotikylistä muuttuivat silmieni edessä. Kertojieni historiakäsitys muuttui, vienalaiset kyselivät malttamattomina toisiltaan, mitä sitten oikein tapahtui. Kuka meidän taloon muutti? Kuka pui viljan? Löytyivätkö meidän kätköt talon takaa? Nyt oli mahdollista kuulla ja kertoa.

Kaikki näytti muuttuvan nopeasti. Ymmärsin, että silmieni edessä tapahtuu jotakin hyvin erityistä. Näiden kokemusten jälkeen tutkimukseni yhdeksi avainteemaksi valikoitui kuin itsestään kertojieni historiakäsitys. Nyt, kaksikymmentäkaksi vuotta myöhemmin, huomaan, ettei muutostilassa ollut vain kertojieni, vaan meidän kaikkien historiakäsitys. Historian julkisia esityksiä muovattiin uuteen uskoon vauhdikkaasti. Julkisten esitysten lisäksi muuttui myös ns. kansanomainen historia, "vaatteisiin tarttuva", kerrottu, puhuttu, yhteisössä elävä historia.

Tutkimukseni rakentuu pakolaisten kertomusten varaan. Niistä muodostuu moniääninen jälki eräästä merkittävästä vaiheesta Suomen ja Itä-Karjalan historiassa. Kertomus paosta on kertomus elämän suuresta käännekohdasta. Usein haastateltava aloitti kertomuksensa kuvauksella paosta.

Pakokertomuksia voisi kutsua käännekertomuksiksi. Ne kuvaavat myöhemmän elämän kannalta ratkaisevaksi osoittautunutta tapahtumaa. Ne ovat yleensä hyvin kiteytyneitä, usein kerrottuja. Ne sisältävät vastauksen hyvin henkilökohtaiseen kysymykseen. Ne kertovat, miten minusta tuli minä, miksi olen täällä, mistä olen tullut, miksi olen sellainen kuin olen.

\section{KULTTUURIN ILMAISUKEINOT OVAT ÄIDINKIELTÄ}

Tutkimukseni painopiste on siis kertojassa tai tekijässä. Hän on kasvanut omaan kulttuuriinsa ja oppinut katsomaan maailmaa sen antamin silmälasein. Suurten elämänmuutosten aikana, uusien elinympäristöjen ja yhteisöjen myötä, hän on oppinut näistä lähtökohdista myös uusia ilmaisukeinoja ja selviytymisen mahdollisuuksia. Hän kertoo kokemastaan niillä tavoilla, joita hän on oppinut, joihin hänellä on sisäinen motivaatio ja jotka tuntuvat uusissa elinympäristöissä mahdollisilta.

Vienalaisissa kyläyhteisöissä taitoja opittiin kuuntelemalla, tarkkailemalla, osallistumalla ja matkimalla. Oman kulttuurin ilmaisukeinot ovat äidinkieltä, tapa katsoa maailmaa. Ilmaiseminen on aina sidoksissa kulttuuriin. Ilmaisukeinojen oppiminen on elinikäinen prosessi; eri elämänvaiheissa opitaan sen ymmärryksen ja niiden keinojen varassa, joita on.

Yhteisön antamalla palautteella voi olla suuri merkitys taitojen kehittymiselle. Oman synnyinyhteisön muuttuessa tai kadotessa kokonaan on uusilla elinympäristöillä ja niiden antamalla palautteella erityisen suuri merkitys: Minkälaisia omana äidinkielenä omaksuttuja ilmaisukeinoja se arvostaa ja tukee? Onko niille paikkaa uudessa elinympäristössä vai onko opittava kokonaan uusia?

Pakolaiset ovat paitsi kertoneet, myös kirjoittaneet kokemuksistaan. Niistä on tehty runoja, kertomuksia ja lauluja. Näiden kertovien jälkien lisäksi kokemuksista on työstetty myös muita jälkiä. Pakolaisten vaiheet näkyvät taideteoissa, joita ovat esimerkiksi maalaukset, pienoismalli, patsaat, musiikkiesitykset ja käsityöt. Ne kaikki kertovat tutkittujeni suhteesta kokemaansa, heidän tavoistaan elää sen kanssa uudessa 
ympäristössä. Pakolaiset ovat kertoneet omista vaiheistaan niillä keinoilla, joita heillä on ollut ja jotka ovat tuntuneet heistä luontevilta.

Kun maisema on muuttunut ja tutut kiintopisteet kadonneet, tarvitaan uusia keinoja kiinnittyä ympäristöön ja kertoa omasta paikasta sïnä. Käsitteenä nimitys arjen taide ei ole vakiintunut, mutta sopisi kuvaamaan ilmiötä pakolaisten kohdalla erityisen hyvin. Pakolaisuudessa juuri normaali arki menetetään, sen sisältö muuttuu ja se on rakennettava uudelta pohjalta. Erilaiset ilmaisukeinot, tekeminen ja työstäminen, voivat tarjota mahdollisuuksia palauttaa menetetty arki ja pitää siitä kiinni, luoda se uudelleen muuttuneeseen tilanteeseen.

\section{TIETEIDEN VÄLISSÄ}

Aloitin tämän työn kulttuurintutkimuksena ja päätän sen kulttuurin- ja taiteentutkimuksen väliin. Molemmilla tieteenaloilla tutkitaan erilaisia jälkiä erilaisista näkökulmista. Olen pyrkinyt siihen, etteivät tutkittavieni jättämät jäljet jäisi minulta huomaamatta siksi, että ne sijoittuvat tieteenalojen väliin. Oman työni kannalta tieteidenvälisyys onkin tarkoittanut laajempaa näkökulmaa ja mahdollisuutta huomata myös sellaista, mikä ei kuulu vain yhden tieteenalan kohteisiin.

En pyri niinkään määrittelemään tutkittavieni taidetekoja taideinstituution näkökulmasta, vaan lähestyn niitä heidän omasta elämänpiiristään käsin, kotipihalta. Tämä ilmaus, kotipihan näkökulma, on eräältä haastateltavaltani. Kun kysyin häneltä Karjalan kapinasta, hän kertoi, että "ne taistothan alkoi meitin pihalta". ${ }^{1}$ Tämä kertomus ei ehkä ole yhteismitallinen historiantutkimuksen tulosten kanssa, mutta se on hänen kokemuksensa tuoma näkökulma ja sellaisena arvokas.

Taideteot ovat pakolaisille omissa elinympäristöissä omaksuttuja ilmaisukeinoja, tapoja olla osallisena maailmassa, kertoa kokemuksista ja tulla ymmärretyksi toisten taholta. Tutkimukseni taidemääritelmän lähtökohtana on oletus, että erilaisille yhteisöille on ominaista kanavoida luovuutta jonkun yhteisössä omaksutun ilmaisukeinon tai välineen kautta. Näin on tapahtunut kautta historian myös sellaisissa yhteisöissä, joissa erillistä taideinstituutiota ei ole tunnettu.

Omien kokemusten ja elämänhistorian tapahtumien kuvaajana juuri taide voi olla merkityksellistä; se voi avata historian aukkoja ja murroskohtia uusin tai kertojalle paljon ominaisemmin keinoin silloin, kun tavalliset sanat eivät riitä. (Reiners 2001, 257.) Luovan prosessin puitteissa myös traumaattisten kokemusten kohtaaminen voi olla mahdollista. ${ }^{2}$

Tutustuminen taidetekojen kenttään on avannut myös tutkimuskohteestani kokonaan uusia asioita. Karjalan pakolaiset eivät ole vain vähemmistö, jota on tulkittu

1 Näin aloitti kertomuksensa kapinavaiheesta yksi haastatelluista. SKSÄ 126127.1991.

2 Reiners (2001, 257). Myös Vettenniemi (2004, 18) ja Gränö (2000, 36 ja 195): ’On mahdollista, että taiteilija tutkii ja tulkitsee taiteessaan juuri niitä hetkiä, joita ei ole jäsennelty kertomuksiksi”. 
enemmistön tarpeista käsin ja sen ehdoilla, vaan joukko ihmisiä, joka on aktiivisesti ottanut haltuun oman historiansa tulkinnan. Tästä kertovat monet muistomerkit ja ITE-taiteen alueelle kuuluvat teokset: ne ovat arjen taidetta, itse tehtyä historiaa, jonka havaitseminen on vaatinut myös tutkijaltaan uusien näkökulmien sisäistämistä.

Tutkimukseni osoittaa, miten monilla tavoilla rajoja ylittäneet ilmaisevat kokemuksiaan - ja miten monilla tavoilla ja tasoilla heidän kokemuksensa kietoutuvat enemmistön kokemuksiin. Tätä rajalla ja rajoilla ilmenevää luovuutta ja pakolaisten tai siirtolaisten erilaisia subjektiviteetin ilmauksia tulisi tutkia eri tieteenalojen näkökulmista. Kertoessaan vähemmistöjen näkökulmista ja elämästä nämä ilmaukset kertovat samalla peilin tavoin myös enemmistöstä.

Hyry Katja 2011: Meistä jäi taas jälki. Miten Vienan pakolaiset etsivätpaikekaansa, kertoivat kokemastaan ja tulivat kuulluiksi 1900-luvun Suomessa. Acta Universitatis Lapponiensis 199. Lapin yliopistokustannus.

\section{LÄHTEET}

Haastattelut:

SKSÄ 126-127.1991.

SKSÄ 127-128.1991.

\section{Kirjallisuus:}

GRANÖ PÄIVI 2000. Taiteilijan lapsuuden kuvat: lapsuus ja taide samassa hetkessä. Taideteollisen korkeakoulun julkaisuja A: 30. Diss. Helsinki: Taideteollinen korkeakoulu.

NYGÅRD TOIVO 1980. Itä-Karjalan pakolaiset 1917-1922. Studia Historica Jyväskyläensia 19. Jyväskylä: Jyväskylän yliopisto.

REINERS ILONA 2001. Taiteen muisti. Tutkielma Adornosta ja Shoahista. Tutkijaliiton julkaisusarja 99. Helsinki. Diss. Helsinki.

VETTENNIEMI ERKKI 2004. Punaisen terrorin todistajat. Neuvostoliitto suomalaisten leirivankien muistelmissa. SKST 957. Helsinki.

Filosofian tohtori Katja Hyry työskentelee päätoimisena tuntiopettajana Helsingin Luonnontiedelukiossa. 